\author{
Olga Novitskaja \\ KU Leuven \\ https://doi.org/10.18485/bgd_nlistiek_30.2018.ch12
}

\title{
EEN DAG VAN DE HEILIGE JORIS: SPREEKWOORDEN IN VERTALING
}

\begin{abstract}
The article analyses and compares idioms of two Slavic languages (Russian and Serbian) and of Dutch. The author explains the difficulties the translator meets while translating these idioms. The translator must always try to translate idioms by idioms but it is not always possible because there is not always an equivalent in the target language or the equivalent is not suitable according to its stylistic features. The strategies for their translation need careful consideration and the translators need deep knowledge of the source and target languages and cultures. There are different strategies in the translation of idioms that illustrate the diverse ways of treatment of this interesting, peculiar and difficult aspect of language. A lot of idioms have an international origin. Some of them preserve the meaning of the original without any change in it, others preserve expressivity of phraseological units, however with some change of their lexical or grammatical features. We need to be careful with the idiomatic false friends that have the same literal meaning in three languages but differ as regards to their idiomatic meaning or their sociolinguistic and stylistic features.
\end{abstract}

Keywords: Idiom, Russian, Serbian, Dutch, translating, false friends, equivalence, collocation

\section{Inleiding}

Ons taalgebruik is doorspekt met beeldspraak. Voor vertalers bieden idiomen en spreekwoorden interessante stof tot nadenken, aangezien die een veelvoorkomend en uitdagend fenomeen zijn dat hun dagelijkse bedrijvigheid kleurt. Tot het idioom behoren ook bestaande uitdrukkingen, spreekwoorden en gezegdes. Steeds meer zegswijzen worden in de media en in de politiek gebruikt. Native speakers herkennen zulke zegswijzen meestal meteen en weten meestal ook waar ze vandaan komen, maar voor anderstaligen blijven ze vaak een linguïstisch raadsel. Wat de semantiek betreft vormen ze daarom ook de meest ingewikkelde lexicale eenheid. Zonder een goede kennis van de idiomen wordt het steeds moeilijker om kranten, televisie of radio in een andere taal op de juiste manier te begrijpen en te interpreteren. In dit artikel worden idiomatische uitdrukkingen met elkaar vergeleken: uit het Russisch, het Servisch en het Nederlands.

De betekenis van fraseologische uitdrukkingen hangt vaak niet af van de betekenis van aparte woorden die er een bestanddeel van zijn. Soms is het zelfs ver zoeken naar een gemeenschappelijke noemer tussen de twee: вотгдесобаказарыта 
(hier is een hond begraven) / u tom grmu leži zec (in deze struik ligt een haas) betekenen in het Nederlands niets anders dan daar ligt de oorzaak. Een volwaardige vertaling moet niet alleen een juiste weergave van een tekst zijn, maar moet ook alle emotionele elementen en de draagwijdte ervan weergeven. Veel moeilijkheden bij het vertalen kunnen opgelost worden door te zoeken naar overeenkomsten en equivalenten wat de inhoud en de betekenis van de taaleenheden betreft. Het zoeken naar equivalenten staat centraal bij de vergelijkende studie van fraseologismen (Płominska 2001: 129).

Mokienko defineert fraseologisme als volgt:

[...] een vaste expressieve woordverbinding die reproduceerbaar is, relatief stabiel in samenstelling en constructie, en een relatief samenhangende betekenis heeft die niet rechtstreeks uit de betekenis van zijn componenten afleidbaar is, welke gedeeltelijk of volledig hun inhoud verloren hebben. (Mokienko 1989: 4. Vertaling O.N.).

Bij de vertaling zijn het ook niet zozeer de individuele woorden die voor problemen zorgen, maar juist de zinswendingen of de frases waarin die gebruikt worden. Daar waarNederlandstaligen iets voor zoete koek slikken en Serviërs onder het woord «hallo!» iets voor lief nemen (zdravo za gotovo), daar nemen Russen iets aan voor zuivere munt (принимаютчто-тоза «чистуюмонету»).

\section{Equivalenten}

Het begrip equivalentie speelt al meer dan een halve eeuw een zeer belangrijke rol in de vertaalwetenschap. De eerste vertaalwetenschappelijke definitie van het concept, in het boek van Vinay en Darbelner 'Comparative Stylistics of French and English', werd vooral op het vertalen van fraseologismen toegepast (Vinay \& Darbelner 1995(1958): 38). In hun boek onderstrepen de auteurs het syntagmatische karakter van equivalenten.

Sommige idiomen en zegswijzen komen in verschillende talen met elkaar overeen. Zulke overeenkomsten kunnen volledig of gedeeltelijk zijn. Zo komt het idioom een kat in een zak kopen, qua inhoud en vorm, in alle drie talen volledig overeen: in het Russisch is het покупатькотавмешкеen in het Servisch kupiti mačku u džaku. Gedeeltelijke overeenkomsten zijn soms te verklaren door het feit dat het gedeelte dat verschilt, grammaticale of lexicale normen aanhoudt die eigen zijn aan het taalsysteem waarin de zegswijze ingezet wordt. Zowel in het Nederlands (en andere Germaanse talen) als in het Russisch bestaat het idioom de rode haan laten kraaien/of op het dak zetten / nуститькрасногопетуха (de rode haan vrijlaten), wat zoveel betekent als 'brand stichten'. Dit voorbeeld toont de gemeenschappelijke Indo-Europese oorsprong aan van sommige idiomen in verschillende talen. "De rode haan was bij deze volkeren een symbool van vuur en zon die als offer aan de goden werd gebracht: Germanen offerden aan Thor (god van de donder en bliksem), Slaven aan Perun (god van de donder) of Svarog (god van het vuur)" (Mokienko 2004: 170. Vertaling O.N.). In het Servisch waar in gelijkaardige situaties de uitdrukking ubaciti žišku (een vonk gooien) 
gebruikt wordt, wijkt het idioom af van het Russisch, de andere Slavische taal, of van het Nederlands.

Hetzelfde kan gezegd worden over het idioom vis noch vlees. Dit idioom komt in het Nederlands en in het Russisch (нирыбанимясо) volledig overeen, zowel wat de semantische invulling als wat de vorm betreft. Het metaforische beeld wordt op dezelfde wijze behouden. Zulke idiomen zijn vaak leenvertalingen uit het Grieks of uit het Latijn. Het Servische idioom "niti smrdi niti miriše" (noch stinkt noch ruikt) komt op semantisch vlak overeen met het zopas vermelde vis noch vlees / нирыбанимясо, maar wordt anders uitgedrukt. Hier wordt een ander beeld ingezet.

Het idioom 'zich in het oor knopen' klinkt anders in het Russisch en in het Servisch: «зарубитьсебе на носу» (zich op de neus inkerven), «utuviti sebi u glavu» (zich in het hoofd kloppen). Wij zien in deze drie talen dezelfde semantische invulling, maar er wordt totaal andere stijlfiguur gehanteerd. Hier moet de vertaler de inhoud van de idiomatische uitdrukkingen doorgeven bij middel van lexicaal verschillende, maar semantisch overeenkomstige uitdrukkingen uit de doeltaal. Letterlijke vertaling zou onbegrip en onjuiste interpretatie met zich meebrengen.

De internationale idiomen horen voornamelijk bij de categorie 'natural equivalence', in tegenstelling tot de categorie 'directional equivalence' waar de interpretatieve en creatieve rol van de vertaler een grotere rol speelt (Pym 2007: 277).

\section{Valse vrienden}

Maar het is oppassen geblazen! Hier kunnen we ook "valse vrienden" tegenkomen. De zegswijze hij heeft er geen kaas van gegeten wordt vaak ten onrechte naar het Russisch vertaald mеt мало каши ел (hijheeft er weinig pap van gegeten) en naar het Servisch mlad $i$ zelen (hij is jong en groen) maar de zegswijze in het Nederlands betekent'geen verstand van iets hebben' en in het Russisch en in het Servisch in iets nog geheel groen zijn, jong en onervaren zijn'. De Nederlandse uitdrukking die hiermee beter overeenkomt is nog niet droog zijn achter de oren. Alhoewel er ook nog moet aan toegevoegd worden dat het Russische idioom nog een andere betekenis met zich meedraagt, nl. 'niet over voldoende kracht beschikken'.

Het idioom een witte raaf, in het Russisch белая ворона, en in het Servisch bela vrana bestaat in de drie door ons behandelde talen, maar waar het in het Nederlands uitsluitend een positieve connotatie uitdraagt, met als betekenis 'een uitblinker', heeft dit idioom in het Russisch en in het Servisch eerder een negatieve bijklank, met als betekenis 'iemand die sterk opvalt door iets wat niet bij andere mensen voorkomt, een zonderling. Deze laatste betekenis wordt in het Nederlands opgevangen door de uitdrukking een vreemde eend in de bijt.

\section{Collocaties}

Naast de problematiek van het vertalen van idiomen en spreekwoorden, willen we ook de vertaling van woordcombinaties aankaarten. Het spreekt voor zich dat 
vaste woordcombinaties uit de brontaal vervangen moeten worden door vaste woordcombinaties eigen aan de doeltaal. Zoniet ontstaat een indruk van kunstmatig en onnatuurlijk taalgebruik. Het letterlijke behoud van vaste woordcombinaties bij het overschakelen van de ene taal naar de andere gaat trouwens vaak in tegen de normen van de doeltaal.

Dit fenomeen van samen voorkomende lexicale elementen wordt in de literatuur met het woord collocatie aangeduid. De term collocatie wordt vaak in verband gebracht met de Britse taalkundige Firth (Firth 1957: 94) die de aandacht vestigde op vaste woordcombinaties die men niet binnen bestaande grammaticale categorieën kan onderbrengen. Susov spreekt over de term collocatie wanneer het voorkomen van bepaalde woorden in het gezelschap van andere woorden "is gebaseerd op een regelmatig karakter van de wederzijdse verwachting, en niet door grammaticale maar wel door semantische factoren wordt bepaald" (Susov 1999: 153. Vertaling O.N.). Collocaties vormen door hun onvoorspelbaarheid een probleem voor taalverwervers. Elke taal heeft haar eigen collocaties en collocaties kunnen, over de talen heen, wel of niet samenvallen. Zo zeg je in het Nederlands als een blok in slaap vallen. Het woord blok heeft verschillende betekenissen in het Russisch maar geen enkele daarvan roept dezelfde associaties op als in het Nederlands. Het woord blok roept in het Russisch de associatie op van iets doms en lomps. In het Servisch vinden wij wel een equivalente uitdrukking: zaspati kao balvan (in slaap vallen als een houtblok). In het Russisch zegt men заснуть как убитый (in slaap vallen als een vermoorde). In het Servisch kan je ook zaspati kao mrtav/kao zaklan (een dode/ neergestokene) zeggen. In het Nederlands wordt er ook slapen als een roos/een baby/ een marmot gezegd. Sommige van deze collocaties komen ook in het Russisch en in het Servisch voor: спать как сурок (marmot), spavati kao mrmot.

De vergelijking zo dom als een uil/een ezel, wordt in het Servisch glup kao noga/kao ćuskija(been/koevoet) en in het Russisch глуn как пробка (kurk). Wanneer iemand hardvochtig, liefdeloos en slecht behandeld wordt, zullen het Nederlands en het Servisch zeggen: iemand stiefmoederlijk behandelen, ponašati se kao maćeha. Hier treft men in het Russisch de uitdrukking aan: держать в черном теле (houden in het zwart vlees). Daar waar in het Nederlands een been slaapt, wordt dat been in het Servisch houterig: noga utrnula en in het Russisch sprakeloos: нога немеет. Hier zien wij weer dat wat in één taal een gebruikelijke collocatie is, enkel ten koste van een bizarre vertaling, op een letterlijke manier van één taal naar de andere kan overgedragen worden.

\section{Uitwisselbaarheid}

Synonieme uitdrukkingen in eenzelfde context zijn over de talen heen niet zonder meer uitwisselbaar. Hoewel synoniemen min of meer dezelfde denotatie hebben, kunnen hun connotaties onderling sterk verschillen. Zo bijvoorbeeld de synonieme uitdrukkingen in het zweet des aanschijns / в nоте тица / и znoju lica svog en handen uit de mouwen steken / засучив рукава/zavrnutirukave die op het eerste gezicht een 
gemeenschappelijke betekenis hebben: onvermoeibaar, zonder ophouden werken. Niettemin leidt een aandachtige analyse van de stilistische kenmerken van deze uitdrukkingen ons ertoe verschillende connotatieve betekenissen te ontwarren, waardoor de context en de situatie waarin elke van deze uitdrukkingen bij voorkeur ingezet zullen worden, een andere gebruikswijze met zich zullen meebrengen. In het $z w e e t$ des aanschijns heeft een bijbelse oorsprong. Als straf voor het overtreden van Gods gebod moeten Adam en Eva werken voor de kost: "In het zweet uws aanschijns zult gij brood eten, totdat gij tot de aarde wederkeert, dewijl gij daaruit genomen zijt; [...]" (Oude Testament. Genesis 3:19). Deze uitdrukking maakt deel uit van wat we als 'internationale fraseologismen' zouden kunnen bestempelen en komt in vele Europese talen voor. In de Westerse linguïstiek spreekt men doorgaans van 'Europese culturele fraseologismen' omdat deze uitdrukkingen verwijzen naar een gemeenschappelijk cultureel erfgoed. Als het fraseologisme in het zweet des aanschijns betekent dat je iets enkel kan bereiken door hard zwoegend te werken, verschuift de betekenis van de uitdrukking handen uit de mouwen steken naar 'vlijtig werk verrichten'. Zoals Barhudarov het opmerkt:

de pragmatische betekenissen sluiten elkaar niet volstrekt uit - tussen de stilistische kenmerken, het register en de emotionele geladenheid bestaat er zo'n hechte band dat er in sommige gevallen moeilijk te bepalen is bij welk type pragmatische betekenis een bepaald kenmerk van woord of woordverbinding gerangschikt moet worden. (Barchudarov 2010: 112. Vertaling O.N.).

We zien dat niet alleen de denotatieve betekenis van uitdrukkingen een rol speelt, maar dat ook de gebruikswijze bepalend kan zijn: in welke situatie en in welke context kan deze uiting ingezet worden? Het gebruik van lexicaal materiaal is niet vrijblijvend. En dit geldt voor alle talen: heel wat woorden worden vaak binnen een vaste woordverbinding gebruikt en elke taal heeft haar eigen specifieke lexicale eenheden die meer dan één enkel woord behelzen. Om het woord honger te intensiveren gebruikt men bijvoorbeeld in het Nederlands niet enkel de vergelijking met het woord wolf maar ook met het zelfstandig naamwoord paard: honger hebben als een paard. In het Russisch en in het Servisch associeert men honger niet met een 'paard' maar wel met een'wolf': голодныйкакволк, gladan kao vuk.

\section{Tot slot}

Idiomen en spreekwoorden vormen een interessant onderzoeksdomein voor vertalers. Een goede kennis van idiomen (vaste zinswendingen en woordverbindingen) zegt veel over de beheersing van een vreemde taal. De contrastieve studie van fraseologismen, idiomen, spreekwoorden en vaste woordverbindingen kan zowel de verwantschappen als de verschillen tussen twee of meerdere talen aantonen.

Tot slot willen we ook de aandacht vestigen op spreekwoorden die een duidelijk cultuurgebonden karakter vertonen. Zulke spreekwoorden kunnen niet 
altijd door equivalente of, qua inhoud, overeenkomstige spreekwoorden uit de doeltaal vertaald worden, omdat de culturele component die deze spreekwoorden meedragen, dan verloren zou gaan. Bijvoorbeeld, de Nederlandse Balken naar Noorwegen zenden of Uilen naar Athene brengen mag men niet altijd vertalen met het Russische spreekwoord В Тулу со своим самоваром не ездят (naar Tula ga je niet met je eigen samowar). Hier lijkt verklarend vertalen vaak een betere optie te zijn, vooral als men met literaire vertaling te maken heeft. Een andere mogelijke optie is het aanwenden van een idiomatische uitdrukking die dezelfde betekenis meedraagt: 'iets ergens naartoe brengen waar dat in overvloed aanwezig is'. Zo bijvoorbeeld: water naar de zee dragen. Het behouden van de betekenis van spreekwoorden is niet alleen belangrijk op zichzelf maar ook, en meer zelfs, om het gebruik van beeldspraak te handhaven. Daarom kunnen we hier een ander beeld aanwenden met een soortgelijke inhoud. Het gebruik in vertaling van cultureel bepaalde uitdrukkingen is vaak ongepast en verwarrend. Men kan niet verwachten dat een anderstalige spreker of lezer de achterliggende informatie kent. Als voorbeeld hiervan willen we ons betoog afsluiten met de Russische uitdrukking Bот тебе бабушка и Юрьев день! (Dat is mij een dag van de Heilige Joris, grootmoedertje!), die gebruikt wordt wanneer iemand onverwachts verneemt dat zijn verwachtingen niet ingelost zullen worden, en er dan alle hoop bij verliest.

\section{Literatuuropgave}

Barchudarov, L.S. 2010. Jazyk i perevod: Voprosy obshej $i$ tshastnoj teorii perevoda. Moskva.

Firth, J.R. 1957. A synopsis of linguistic theory 1930-1955. Studies in Linguistic Analysis, 1-32. Oxford: Philological Society.

Mokienko, V.M. 1989. Slavjanskaja frazeologija. Moskva.

Mokienko, V.M. 2004. Davajte govorit pavilno! Sankt-Peterburg.

Pym, A. 2007. Natural and Directional Equivalence in Theories of Translation. Target, Vol. 19/2, pp. 271-294.

Płominska, M. 2001. Zur Übersetzungsäquivalenz deutscher und polnischer Phraseologismen mit Farbbezeichnungen. Glottodidactica. Vol. 29, pp. 129-137.

Susov, I.P. 1999. Istorija jazykoznanija: Uchebnoje posobije dlja studentov starshih kursov $i$ aspirantov. Tver

Vinay, J-P., Darbelner, J. (1958) 1995. Comparative Stylistics of French and English: A Methodology for Translation. Amsterdam/Philadelphia.

1 In de $15^{\text {de }}$ eeuw konden boeren een week voor het naamfeest van de Heilige Joris en een week nadien van één eigenaar naar de andere overgaan. Op het eind van de $16^{\text {de }}$ eeuw werd dat afgeschaft en waren de boeren tot hun dood lijfeigenen van één landheer. 